Received: 16/7/2019

UDK: 373.2-051:373.2.035

Original scientific paper

\title{
KINDERGARTEN TEACHERS AS MODELS AND FACILITATORS OF SOCIALISATION IN THE KINDERGARTEN
}

\author{
Nataša Vlah \\ Faculty of Teacher Education \\ University of Rijeka \\ natasa.vlah@uniri.hr \\ Lucija Jančec \\ Pupil residence "Podmurvice", Rijeka \\ Maja Sabolić \\ Zlatko Grgošević Music School, Zagreb
}




\section{ABSTRACT}

Within the social learning theory, the following goals were set: (i) to state whether kindergarten teachers apply appropriate and theoretically suitable forms of professional social behaviour through means of participatory observing, and (ii) to analyse their reflective review based on observed professional social behaviour. Ten social behaviours were observed using a form provided by the Participatory monitoring protocol, and a semi-structured reflective questionnaire was conducted with every participant after all the data were collected. Results show that warm and pleasant communication with children, clear and unambiguous instructions for activities, coherent verbal and non-verbal communication, carefulness in listening to children, and eye contact are mainly present in the behaviour of kindergarten teachers. On the other hand, activities that stimulate speech, open-ended questions, warning children discreetly, waiting for the child to finish talking, and articulate speech are less present. In terms of reflections, all three participants show self-criticism and a rational wish to improve their quality of work performance.

Key words: kindergarten teachers, social learning theory, socialisation, reflective practice, hidden curriculum 


\section{INTRODUCTION}

The kindergarten is a place of cohabitation for children, parents and all the kindergarten staff, with kindergarten teachers who excel with specific competencies. By reflection they shape educational aims, organise the day rhythm and the child's whole environment. They plan and programme their work, making decisions independently about their own procedures, as well as about their communication with children and other subjects. At the same time it is of utmost importance to understand children development, their communication-interaction knowledge and skills (Mlinarević, 2000), and by consciously including their own behaviour and reactions, they can influence the child in a constructive and stimulating way. In other words, for an optimal child development in the kindergarten, the role of kindergarten teachers is of key importance. They continually form an environment supporting learning (Slunjski, 2008; Mlinarević, Tomas, 2010; Jurčević Lozančić, 2016) through the organisation of activities, structuring time and space, which implies kindergarten teachers' adequate professional social behaviour (Jurčević Lozančić, 2011; Družine, Velan, 2017) which is part of the hidden curriculum ${ }^{1}$ (Vlah et al., 2015; Jančec et al, 2015) directed toward positive children development. Although the kindergarten teachers' professional social behaviour is in a way expected and implied by the fact that they attained a verified document by completing their initial professional education, it is necessary to investigate if kindergarten teachers apply the theoretical postulates and principles in their work when it is known that they can have a constructive and stimulating effect on the child.

\subsection{Kindergarten teacher as the facilitator of the child's life in the kindergarten}

Besides the kindergarten teachers' professional characteristics given in the introduction, the value of the behavioural component in education can be understood as "invisible to the human eye", the concealed component of the kindergarten curriculum, the hidden curriculum. Since the occurrences of the hidden curriculum are "hard to catch" (Dolar Bahovec, Bregar Golubič, 2004) and are certainly part

1 An experience through which pupils simultaneously form a collection of interaction processes which appear as part of interpersonal relationships and everyday life with the kindergarten teacher, through their verbal and non-verbal behaviour, has a significant influence on the shaping and behaviour of a child. Therefore, the relationship between the pedagogic intention and pedagogic outcome can be understood only by accepting this invisible reality, the hidden curriculum (Bloom, 1972, Seddon, 1983, Cindrić et al., 2010, Miljak, 2007, Bašić, 2000, all acording to Vlah et al., 2015:127) 
of the educational institution's culture (Vrcelj, 2003; Vujičić, 2011), the behaviour observation pattern along with an accompanying reflection of those participating in the observation can contribute to the description, detection and raising the awareness of the role of the kindergarten teacher as the facilitator and motivator of socialisation changes in the kindergarten. It includes the kindergarten teacher as an active and motivating positive model of socialisation in the kindergarten. The kindergarten teachers' professional behaviour implies implicit kindergarten teachers' pedagogies, often named subjective theories, and they relate to the way of selection and evaluating information which enable reaching conclusions, and are primarily shaped in the interaction with others important to that person (Trunšek, 2008). Petrović Sočo (2009) adds that by changing the kindergarten teachers' individual, subjective theories, the institution's culture also changes, which has also been confirmed by her three-year action research.

Additionally, the finding that kindergarten teachers who participated in the action research were more competent for the organisation of a supportive spatialmaterial environment in the kindergarten is interesting, since it means that they incite children for research activities and companionship, but also enable learning by doing and cooperating. Such kindergarten teachers are also more successful in setting a flexible organisation of time in the institution, thus supporting the individual diversity of children learning (Slunjski et al., 2006). Lesourne (2000) adds that the contribution of the school, which can also relate to kindergartens, does not completely lie in the special programmes suggested by the school, but in the creation of a meaningful relationship between a certain number of areas different from each other, which is especially shaped by kindergarten and school teachers in their practice. This even puts a light on the "black box" of education described by Hargreaves and Fullan back in 1992, and relating to the performance of teaching, the sole realisation of the educational process in practice, and the hard accessibility of the mentioned phenomena in the rational analysis. In kindergartens, the illumination of the "black box" can be achieved by observing the significance of the kindergarten teacher as a model and facilitator, but in aspects of everyday professional procedures they bring closer, explain and help children to understand their environment, while analysis only discloses their implicit significance in practice. By all formerly described, kindergarten teachers approach their mission of helping the children to achieve the propositions they have in themselves, thus creating conditions, the environment and atmosphere for the child to achieve them. Children's natural learning is a result of their playing experience since it activates the formation of various experiences, occurrences, ideas, emotions and new situations which remain deeply woven into personal cognitions, and it is necessary to study and understand them (Jurčević 
Lozančić, 2016), while the way children participate in institutional practices and what they learn from such experience can lead to their developmental changes. It is possible to analyse such changes in relation to the children's social situation or the specific context in which children's everyday activities occur (Fleer, Hedegaard, 2010), which means that children define their world and build their understanding of the environment according to their own cognitions.

\subsection{Learning and the life of early and preschool children in the kindergarten}

Early and preschool children's learning in the kindergarten occurs as a whole and implies the activation of their intellectual, social, moral, spiritual and motor development (National Curriculum for Early and Preschool Education, 2014). It is based on the revelation, interpretation, reflection and understanding of experience, which is a set process in which children represent views, present their understanding, negotiate, reorganise and reconstruct through a two-way communication with those surrounding them. Children are active subjects in the learning process, and their feeling of belonging to the community and acceptance is most important (Slunjski, 2011). They learn from the environment they live in, they observe from the behaviour "occurring" around them, which has also been explained by Bandura's theory of social learning (Bandura, 1986). At the same time, it is important to bring to consciousness that with positive forms of professional social behaviour, modelling by observing the model, children can learn the negative behaviours, too (for instance, insincerity, aggressiveness, cheating, etc.). However, regarding the fact that the social interaction between kindergarten teachers and children represents a model for the development of the social competence, i.e. handling of social skills, with their own adequate professional social behaviour serving as an example to children, the kindergarten teacher should also observe the acquisition of children's social skills and interactions among them. The ground for that can be found in the fact that games and action among children, by respecting the formerly set rules, represent constituents of children's social interaction (Jurčević Lozančić, 2016). Kindergarten teachers do all of that with the aim to develop a socially competent individual, the one who can use the support of the environment and his or her personal potentials and so achieve good developmental results (Katz, McClellan, 1999), which is especially relevant for children with risky behaviour who need additional adaptations, support and help for an optimal psycho-social development (Vlah et al., 2014; Vlah, Ferić, 2017). Consequently, in the kindergarten children learn their speech according to the contents presented by kindergarten 
teachers as models and main ideal, while the incitement of speech development is not compressed in time-limited activities because communication happens in every moment spent with children (Velički, 2009). Kindergarten teachers bear in mind, during the incitement of children speech, that development depends on the children's physical skilfulness and rough motor fitness, which is the base for the development of fine motor skills, all connected to speech development (Katarinčić, Velički, 2011). Not only is the amount of interaction of the adult with children important, but also its quality. Children will be supported in their speech development if they are treated as equal speech partners, whose interest in communication is the most important, which contributes to cooperation and the development of confidence in their own abilities. Therefore, activities are designed which satisfy their personal challenges and are connected with their relevant knowledge, and they condition such an atmosphere where children can use the acquired knowledge and skills in their cooperation and playing with others (Bruner, 1981).

The research part will, in a systematic and as objective as possible way, notice, note and analyse how some relevant professional social behaviours applied by the kindergarten teacher in her work to model and facilitate children development are conducted in practice. That is why the authors of this paper wanted to give a contribution to the knowledge about the kindergarten teachers' professionalism in the direct educational work. It is the partial evaluation of one part of the professional paper relating to the professional social behaviours based on communication and procedures in the everyday routine of the kindergarten and the educational group. The applicative value of this paper is to give recommendations for the advancement of the educational practice in line with the research results. Similar research studies have already been conducted in Croatia (Kožić et al., 2013); Družinec, Velan, 2017), and this research wants to give a contribution to the knowledge which already exists after these insights. Kožić et al. (2013) used the Flander's model of interaction and studied if there were differences in the use of different channels of non-verbal communication among pre-service and in-service teachers, and determined the opposite of what had been expected. More precisely, they determined that there were no differences in interaction among current and future professionals, which represented a change from the formerly obtained findings of other research studies. Similarly, Družinec and Velan (2017) studied the strategies used by the kindergarten teacher to facilitate social interactions in her direct work with children, and the results they obtained showed that there was ample use of adequate working methods in practice, such as talking with conflicting children instead of punishment, giving suggestions instead of orders in social interactions, asking questions and showing an interest for children's opinions, consideration of 
children's ideas and encouragement to express their own wishes, encouragement of children to cooperation and suggesting sentences to support cooperation, ensuring alternatives to tattling, encouraging children to be patient, altruistic and emphatic, to alternatively interpret someone else's behaviour, encouraging them to ask questions and the use of polite phrases in conversations with children, which all fill the kindergarten teacher with satisfaction.

\subsection{Research aims}

This research aims are (i) to use participatory observation and determine if kindergarten teachers use appropriate and theoretically adequate forms of professional social behaviours and (ii) to analyse their reflexive overviews of the determined results of professional social behaviours in the group. It can be expected that kindergarten teachers mostly use adequate and theoretically appropriate forms of professional social behaviours and that in their reflection about the obtained results they are self-critical and rationally directed toward improvements of their own work.

\section{METHOD}

\subsection{Sample of participants}

Three female kindergarten teacher of the "Šegrt Hlapić" kindergarten participated in the research. All of them were of a relatively younger age and shorter work experience (A.LJ. is a kindergarten teacher of an older nursery group with an additional programme of English language teaching, she is 31 years old and has nine years of work experience, and is currently attending the graduate study of Early and Preschool Education in Zagreb; L.P. is a kindergarten teacher of a younger kindergarten educational group, she is 27 years old with four years of professional experience, and is additionally trained to lead a sports programme group; M.R. is a kindergarten teacher of a younger kindergarten group, she is 35 years old with three years of working experience, and is additionally trained to work with children with special needs).

\subsection{Measuring instrument and procedure}

A protocol prepared for this research was used, namely the Form for Kindergarten Teachers' Behaviour Observation (more see in Sabolić, 2018) which served 
to monitor the professional social behaviours of kindergarten teachers toward children, modified after the Flander's model (Flander's Interaction Analysis - FIA, 1970) from the research about non-verbal communication channels in teaching (Kožić et al., 2013), as well as a semi-structured questionnaire for kindergarten teachers' reflection (adapted from Družinec, Velan, 2017). The ten chosen kindergarten teachers' professional social behaviours in their work with children were created and constructed by Sabolić $\left(2018^{2}\right)$ in collaboration with her mentor, relying on a similar model by Kožić et al. (2013):

- During communication with the children the kindergarten teacher establishes eye contact

- The communication with children is emotionally warm and pleasant

- She talks clearly and audibly (she does not babble to children, her speech is correct in terms of articulation, she does not talk too fast, incorrectly)

- She asks open-ended questions, such as: "How did you do that?", "How was it?", "What were you doing there?", "Describe what you did", "What happened in the story?"

- Non-verbal communication (gestures, facial expression, "body language") fits the verbal (speech)

- She carefully listens to children indicating that she is listening to them (for instance, with non-verbal signs: nodding, or verbal: "Yes", "Aha”)

- She carefully waits for the children to finish what they wanted to say

- If children often shout or abuse their voice in any other way, she discreetly warns them

- She conducts activities supporting the development of speech, language and narration with children (stories, picture books, drama and scene activities, songs, rhymes)

- She gives clear and unambiguous instructions to children for the fulfilment of a certain activity.

The three five-minute time intervals during which the kindergarten teachers' professional social behaviour was observed were (i) during breakfast, (ii) during the morning circle and (iii) during the offered materials and activities. They were chosen due to the knowledge of the daily activities' exchange rhythm of the institutional life of early and preschool children. Professional social behaviours were observed and monitored in a five-minute period during ten days, and each of the three kindergarten teachers filled out a total of thirty forms of the protocol of participatory observation. After a few months' period of getting to know the group

2 The results presented in this work were part of a research conducted by Sabolić (2018) in a pre-project of the project „The Croatian Teachers' Professionalism for the Educational Inclusion of Pupils with Behaviour Disorders" uniri-drustv-18-98 1233 
and the kindergarten teachers and children getting used to the observer in the group, the observer filled out the protocol during the chosen time intervals, and made an annotation about the mentioned behaviours as a) insufficiently present, b) sufficiently present or c) not applicable (a certain kindergarten teacher's behaviour is not applicable due to circumstances, for example, watching a puppet show). Besides the already mentioned, at the end of the form for the observation of behaviours there is a section for possible comments and remarks. All kindergarten teachers willingly participated in the research, while each time the observer came to the educational group was announced and agreed upon in advance, children knew and were used to the observer (employee of the mentioned institution), and the parents of children in the educational groups where the research was conducted were informed about the reasons for the research and gave their informed consent (for a more detailed description of data collection see Sabolić, 2018).

The second used measuring instrument was a semi-structured questionnaire for kindergarten teachers' reflection, after they got an insight into their own results on the Form for Kindergarten Teachers' Behaviour Observation. The semistructured questionnaire was conducted individually and orally, immediately after the application of behaviour monitoring, while to each of the three kindergarten teachers the researcher directed three short open-ended questions: What do you think of the research results regarding your represented professional social behaviours? What kind of results were you hoping for? How do you like the conducted research and how did it help you? The interview was recorded and afterwards a transcript was made. After the conducted reflection, kindergarten teachers had an insight into their own reflections and gave their consent for the presentation of the same.

\subsection{Data processing}

In the processing of the obtained data all the insufficiently present, sufficiently present and not applicable professional social behaviours were summed up for all three kindergarten teachers at all points in time, while in interpretations the results are presented as absolute numbers and percentages. The observer's criterion for the choice of "sufficiently present" or "insufficiently present" was the professionalism of the observer who is a master of early and preschool education and graduate at the study of pedagogy, with a three-year work experience in the kindergarten. The presence of behaviours was estimated in relation to contextual relevance. For example, the item "She carefully waits for the children to finish what they wanted to say" was estimated in the context of a concrete interaction between the kinder- 
garten teacher and child in the observed moment, i.e. five-minute interval. Since the occurrence of various forms of professional social behaviours was observed, it was enough for certain behaviours to occur, for instance, twice to three times in an observed period (for example, pleasant communication) to be estimated as sufficiently present, while for some other behaviours, even if they occurred more than twice or three times (for example, harmonising verbal and non-verbal communication), they were estimated as insufficiently present if the behaviour was insufficiently present regarding the need. Sufficient/insufficient presence depends on the observer's subjective evaluation, i.e. on his/her view of the need for a certain behaviour in relation to the true occurrence of the behaviour. After the numerical processing and interpretation of results, a half-hour reflection was conducted individually with each kindergarten teacher.

\section{RESULTS AND DISCUSSION}

The results will be presented so that the chosen ten observed professional social behaviours will be followed according to the described Form for Kindergarten Teachers' Behaviour Observation, with the observed teachers' behaviours put into a table for an easier review of results. For each of the ten observed behaviours relevant obtained depositions in the participators' reflections will be chosen. The criteria for the relevance of the chosen reflection will be the kindergarten teacher's understanding that there are certain areas of her work which could or should be improved, but also her explanations of specific situations and why she used or did not use some behaviours in certain interactions with a child/children in her group.

\subsection{During communication with the children the kindergarten teacher establishes eye contact}

According to the protocol of participatory observation, during breakfast and offering materials and activities, the first kindergarten teacher established insufficient eye contact, totally six times, while sufficient eye contact was present 23 times in all observed periods, as presented in Table 1., while in one occasion this behaviour was not adequate for observation. Boyes (2009) emphasizes that the position of the head and eyes reveals the speaker's intentions. For instance, the wish for a talk and open communication can be seen in directly looking the interlocutor in the eyes. This kindergarten teacher emphasizes that she is putting an effort into taking care about her body position and the level of the child's eyes. As for the second teacher, insufficient eye contact was present only once during breakfast 
and twice during offering materials and activities, so three times in total, while it was sufficiently present 27 times. This kindergarten teacher shows satisfaction during the reflection because in most of the cases the eye contact with children was established, which is extremely important for the establishment and keeping the communication going, and indicates trust and directing attention. The third kindergarten teacher established insufficient eye contact 10 times, mostly during offering materials and activities and during breakfast, while sufficient eye contact was achieved 20 times, mostly during the morning circle. In her reflection the kindergarten teacher explained that probably there was no need for that at some points of observation and that at the time children were in their own activities. She explained that probably she did not make an appropriate evaluation about the need of this form of communication and approach in the work with children, and she pointed out that this would be a priority to work on during her further work. Borbonus (1997, according to Velički, 2009) emphasizes the importance of adequate interaction with children from the earliest age, as well as the evidence of a lack of active talks with children, while Boyes (2009) warns that eye contact is a basic means for non-verbal communication.

Table 1. Display of the representation of observed items; $\mathrm{O} 1$ = first kindergarten teacher; $\mathrm{O} 2$ = second kindergarten teacher; $\mathrm{O} 3$ = third kindergarten teacher; $\mathrm{NO}$ insufficiently present, YES - sufficiently present

\begin{tabular}{|c|c|c|c|c|c|c|c|c|c|c|c|c|c|}
\hline \multirow{2}{*}{$\begin{array}{l}\text { Item } \\
\text { Kindergarten } \\
\text { teacher }\end{array}$} & & \multicolumn{3}{|c|}{$\begin{array}{c}\text { Breakfast } \\
(\mathrm{N}, \%)\end{array}$} & \multicolumn{3}{|c|}{$\begin{array}{l}\text { Morning cycle } \\
(\mathrm{N}, \%)\end{array}$} & \multicolumn{3}{|c|}{$\begin{array}{c}\text { Offering materials } \\
\text { and activities } \\
(\mathrm{N}, \%)\end{array}$} & \multicolumn{3}{|c|}{$\begin{array}{l}\text { Total } \\
(\mathrm{N}, \%)\end{array}$} \\
\hline & & $\mathrm{O} 1$ & $\mathrm{O} 2$ & O3 & $\mathrm{O} 1$ & O2 & O3 & $\mathrm{O} 1$ & $\mathrm{O} 2$ & $\mathrm{O} 3$ & $\mathrm{O} 1$ & O2 & O3 \\
\hline \multirow[b]{2}{*}{$\begin{array}{l}\text { During } \\
\text { commu- } \\
\text { nication } \\
\text { with the } \\
\text { children the } \\
\text { kindergar- } \\
\text { ten teacher } \\
\text { establishes } \\
\text { eye contact }\end{array}$} & YES & $7(70 \%)$ & $9(90 \%)$ & $7(70 \%)$ & $9(90 \%)$ & $\begin{array}{c}10 \\
(100 \%)\end{array}$ & $9(90 \%)$ & $7(70 \%)$ & $8(80 \%)$ & $4(40 \%)$ & $23(76.66 \%)$ & $27(90 \%)$ & $\begin{array}{c}20 \\
(66.66 \%) \\
\end{array}$ \\
\hline & NO & $3(30 \%)$ & $1(10 \%)$ & $\begin{array}{c}3 \\
(30 \%)\end{array}$ & $\begin{array}{c}0 \\
(0 \%)\end{array}$ & $\begin{array}{c}0 \\
(0 \%)\end{array}$ & $1(10 \%)$ & $\begin{array}{c}3 \\
(30 \%)\end{array}$ & $\begin{array}{c}2 \\
(20 \%)\end{array}$ & $\begin{array}{c}6 \\
(60 \%)\end{array}$ & $\begin{array}{c}6 \\
(20 \%)\end{array}$ & $3(10 \%)$ & $\begin{array}{c}10 \\
(33.33 \%)\end{array}$ \\
\hline \multirow{2}{*}{$\begin{array}{l}\text { The com- } \\
\text { munica- } \\
\text { tion with } \\
\text { children is } \\
\text { emotionally } \\
\text { warm and } \\
\text { pleasant }\end{array}$} & YES & $9(90 \%)$ & $\begin{array}{c}10 \\
(100 \%)\end{array}$ & $8(80 \%)$ & $9(90 \%)$ & $\begin{array}{c}10 \\
(100 \%)\end{array}$ & $8(80 \%)$ & $9(40 \%)$ & $9(90 \%)$ & $9(90 \%)$ & $27(90 \%)$ & $\begin{array}{c}29 \\
(96.66 \%) \\
\end{array}$ & $\begin{array}{c}25 \\
(83.33 \%) \\
\end{array}$ \\
\hline & NO & $1(10 \%)$ & $\begin{array}{c}0 \\
(0 \%)\end{array}$ & $2(20 \%)$ & $\begin{array}{c}0 \\
(0 \%)\end{array}$ & $\begin{array}{c}0 \\
(0 \%)\end{array}$ & $\begin{array}{c}2 \\
(20 \%)\end{array}$ & $\begin{array}{c}0 \\
(0 \%)\end{array}$ & $\begin{array}{c}0 \\
(0 \%)\end{array}$ & $0(0 \%)$ & $1(3.33 \%)$ & $0(0 \%)$ & $\begin{array}{c}4 \\
(13.33 \%)\end{array}$ \\
\hline \multirow{2}{*}{$\begin{array}{l}\text { She talks } \\
\text { clearly and } \\
\text { audibly }\end{array}$} & YES & $\begin{array}{c}10 \\
(100 \%)\end{array}$ & $8(80 \%)$ & $9(90 \%)$ & $9(90 \%)$ & $7(70 \%)$ & $9(90 \%)$ & $7(70 \%)$ & $3(30 \%)$ & $7(70 \%)$ & $26(86.66 \%)$ & $18(0 \%)^{2}$ & $\begin{array}{c}25(83.33 \\
\%) \\
\end{array}$ \\
\hline & NO & $0(0 \%)$ & $2(20 \%)$ & $1(10 \%)$ & $\begin{array}{l}0 \\
(0 \%)\end{array}$ & $\begin{array}{c}3 \\
(30 \%)\end{array}$ & $\begin{array}{c}1 \\
(10 \%)\end{array}$ & $\begin{array}{c}1 \\
(10 \%)\end{array}$ & $\begin{array}{c}6 \\
(60 \%)\end{array}$ & $2(20 \%)$ & $1(3.33 \%)$ & $\begin{array}{c}11(36.66 \\
\%)\end{array}$ & $\begin{array}{c}4 \\
(13.33 \%)\end{array}$ \\
\hline
\end{tabular}




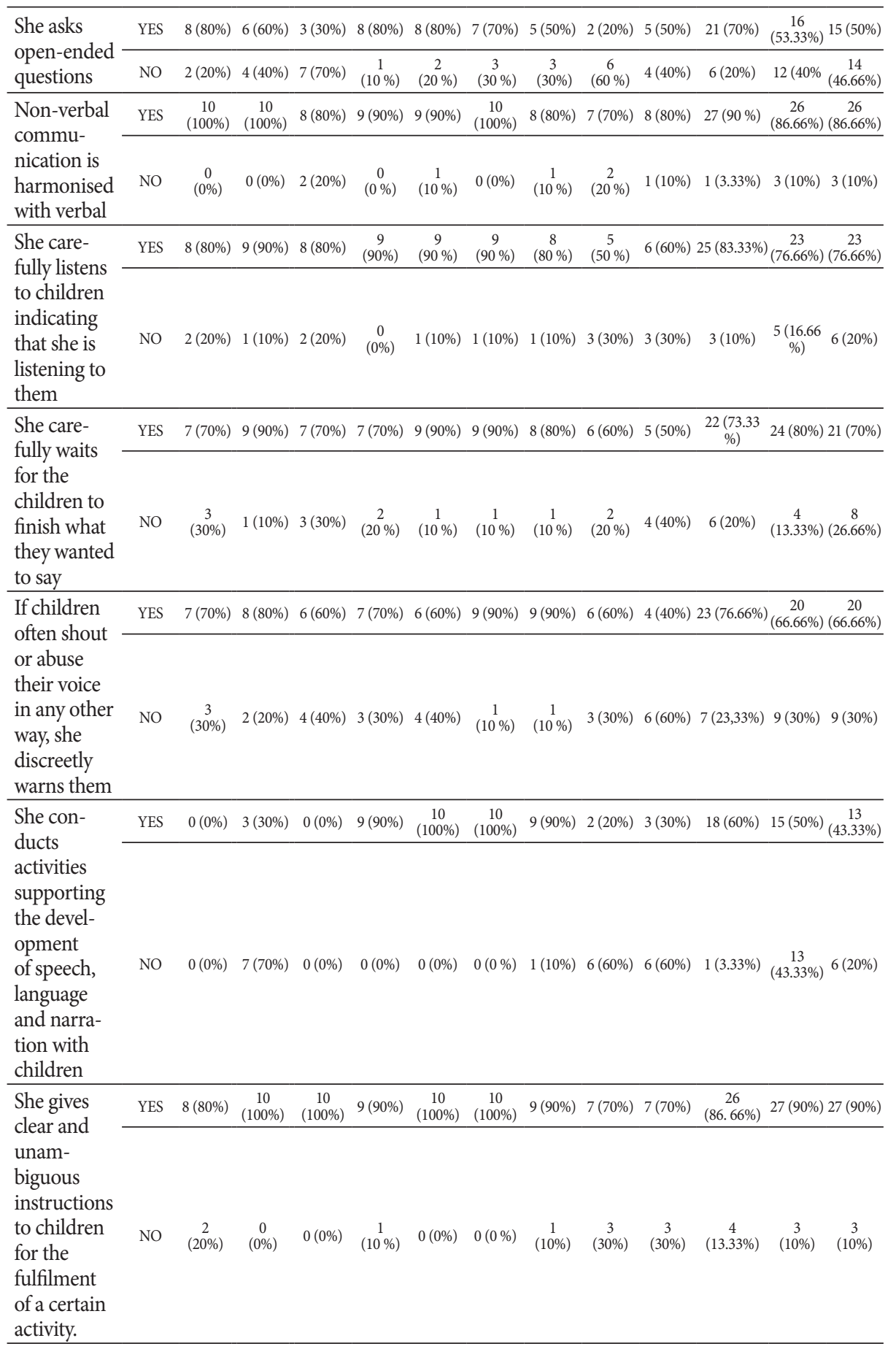




\subsection{The communication with children is emotionally warm and pleasant}

Keeping an emotionally warm and pleasant communication with children was insufficiently present only once, during breakfast, in the first kindergarten's teacher behaviour, while it was sufficiently present 27 times, and the behaviour could not be assessed twice. This teacher expressed her satisfaction with the result claiming that taking care about the children's environment is necessary and that the pleasant communication in which children spend time is basic if the aim is for children to acquire correct communication skills. The acquisition of basic communication rules enables adults to really hear and accept children, consequently teaching them how to communicate successfully (Zrilić, 2010). As for the second kindergarten teacher, a sufficiently present emotionally warm and pleasant communication with children occurred 29 times, its insufficient presence was never observed, while once the behaviour was not suitable for observation. This teacher, according to reflection, was satisfied that pleasant communication was really present in her work, and she is convinced that this is important to encourage children to solve problems in the right way, incite and motivate them to engage into activities and direct their attention to important elements. She then pointed out that children learnt by experiencing, by their presence in such an environment children acquired the experience of warm behaviour and pleasant communication thus also acquiring skills important for life. Jurčević Lozančić (2016) emphasizes that children's natural learning is the result of their experience through games in a pleasant environment. They thusly activate the creation of experience which remain deeply engraved in their personal cognition for a long time. Regarding the third kindergarten teacher, an emotionally pleasant and warm communication with children was insufficiently present four times in total, during breakfast and the morning circle, it was sufficiently present 25 times, while the behaviour was not suitable for observation in one case. In her communication with children, this teacher used humour and communicated with them in a representative and interesting way. This teacher's communication with children was of a happy character, friendly tone, and the atmosphere of trust could be felt. Ruch (1998, according to Tatalović Vorkapić, Srok, 2014) points out that humour implies a concept with cognitive, emotional, behavioural, psychophysiological and social components. Zillmann et al. (1980) remarks that the appearance of humour ensures raising and prolonging the duration of children's attention and makes it easier for children to master skills and learn. 


\subsection{The kindergarten teacher talks clearly and audibly}

The first kindergarten teacher's speech was inarticulate, non-fluent and unclear once during offering materials and activities, 26 times in total it was sufficiently clear, audible, correct in terms of articulation with a moderate speech tempo and fluent, while the behaviour was not suitable for observation three times. This teacher did not babble to children, in most of the cases her speech was clear and articulate for all the children to hear and understand her. According to reflection, she tries to emphasize important instructions with her tone, change her speech pace during reading of stories and talks with children as to avoid boring and monotonous speech, and she pays attention to express herself as sufficiently correct as possible. Furthermore, as many as 11 times the second kindergarten teacher's clear and articulate communication was insufficiently present, mostly during offering materials and activities, but also during the morning circle and breakfast, while it was sufficiently present in only 18 cases. In one case this behaviour was not suitable for observation. Through reflection, this teacher expressed her dissatisfaction with results, and she was happy that this research made her conscious of this. The situations encompassing an insufficient presence of clear and articulate speech regard those situations where the teacher babbles too much, in some occasions, at pronouncing words, she "swallows" syllables or talks too fast and inaudibly which made it harder for children to understand her verbal instructions. She considered that to be a flaw in her educational work since the lack of teachers' adequate speech (offering a speech model to children) can negatively influence children's speech development.

Rade (2003) warns that the older the child, the more unwanted babbling, softening the pronunciation of voices and overuse of diminutives. Velički (2009) remarks that children do not learn to speak in a determined and separate time, but constantly, so it is important how the kindergarten teachers express themselves because children learn the content that they present as speech models. In the case of the third kindergarten teacher, clear and articulate speech in her work was insufficiently present four times, during offering materials and activities, but also during the morning circle and breakfast, and it was sufficiently present 25 times, with one occasion when the behaviour was not suitable for observation. According to observation, this teacher was also satisfied with the results of this behaviour presence. She claimed that to perform the job of a kindergarten teacher it was really important for the speech to be correct, not only because children learn to speak from them, but to avoid the label that children "are not obedient and do not listen" while maybe they did not hear or understand the instruction which was maybe too long, ambiguous or unclear. She then emphasized the importance of other work 
segments. This is all also claimed by Loughran (2002) who emphasizes the importance of reflecting the practice, identification, questioning, reflection, support, selfevaluation and self-development, as well as self-consciousness about one's work.

\subsection{The kindergarten teacher asks open-ended questions}

The results show that the first kindergarten teacher insufficiently asked openended questions in her communication with children six times, mostly during offering materials and activities, less during breakfast and the morning circle, while asking open-ended questions was sufficiently present 21 times. Observation was not applicable three times. The interview with the teachers shows her satisfaction with the representation of this behaviour. She is of the opinion that this kind of questions can penetrate children's thoughts best, and that they stimulate children's speech and widen their vocabulary since the child does not shortly answer YES/NO, but is motivated to describe and individually reflect with as comprehensive speech expressions as possible. She can thus notice the improvement made by a child and so make further plans and programmes to work with a certain child. The second teacher had a total of 12 insufficient uses of open-ended questions in her communication with children, mostly during offering materials and activities and during breakfast, this kind of questions were sufficiently present only 16 times, while the behaviour was not suitable for observation in two cases. During the interview with the teacher great dissatisfaction was found on her side linked to this result. She noticed that the largest number of insufficiently present behaviour was present during morning activities, and she explained that usually during the morning circle she motivated children by talking about the planned activities, and that during morning activities she mostly acted as an observer or guide if necessary. She did not interfere in children's games and did not act as a partner, but used this time to monitor children and see which developmental area she should work on with a certain child. She also gave a comment that open-ended questions needed a lot of time, and due to the large number of children in the group there were constant situations which did not make it possible for her to conduct such conversations more often, although she was familiar with the essence and importance of such communication.

Ljubetić (2009) warns that the way people communicate greatly influences the creation and development of quality relationships which are reflected on the mood and emotions of an individual. According to Petrović-Sočo (2000), the kindergarten teacher, during performing his/her pedagogic activities, can take different contemporary roles (supplier, observer, supporter, guide, helper, evaluator, co-player, planner, leader), but has to be flexible in the organisation of the environment and 
choice of role according to the momentary relevant children's needs and interests. When it comes to the third kindergarten teacher, she sufficiently used open-ended questions only 15 times in her work, with even 14 times of insufficient use, mostly during breakfast, somewhat less during offering activities and during the morning circle, while in one case the behaviour was not suitable for observation. This teacher was negatively surprised by her result. She was of the opinion that for such a conversation form an individual approach to the child was necessary, and the morning period was most suitable for that, the time of the morning gathering and breakfast, when there were still not so many children in the day room. She noticed that in her work asking closed-ended questions was more present in the morning and during morning activities, and she remarked that due to the large number of children it was difficult to dedicate herself to each one that way. She explained that the morning circle was also adequate for such communication because the whole group attention was then directed toward her, the children listened to her and to each other attentively and such a conversation could be conducted.

Open-ended questions give an opportunity to the persons talking to better express themselves, while Žižak et al. (2012) add that open, sincerely asked questions arising from true interest of the listener in what the interlocutor wants are especially encouraging for further deepening their mutual understanding, which is the most wanted result of each communication.

\subsection{The kindergarten teacher harmonises non- verbal and verbal communication}

During the observed educational work, the first teacher insufficiently harmonised her non-verbal communication (gestures, facial expressions, "body language") to verbal in only one case, during offering materials and activities, while harmonising verbal and non-verbal communication was sufficiently present in 27 cases. This behaviour could not be observed in two cases. Through reflection it can be seen that the participator was happy with this result. She remarked that she had attended the course Communicology during her studies and that she was present at workshops during her professional training linked to body language, taking care that her speech expression be followed up by appropriate facial expressions. The moment linked to the insufficient harmonisation of verbal and non-verbal communication regarded a moment when a boy was disturbing the other children in their activities and the teacher was telling him she was angry because he was doing that. However, this emotion could not be read on her face, but there was a moderate smile because the teacher was in a parallel communica- 
tion with another girl. The boy may not have understood the sent message due to the contradictory message sent by her verbal and non-verbal communication. The awareness of non-verbal communication and harmonisation of verbal expression with non-verbal communication is important because sometimes it is out of the speaker's control, and has a great influence on reliability and credibility (Brajša, Vučetić, 1990). Zrilić (2010) singles out that the kindergarten teachers themselves are models for children's learning of behaviours (verbal/non-verbal) because by communication, control and regulation of emotions, sympathising, tolerating and cooperation children learn how to satisfy and accept their own and other's needs, as well as to listen to and support others.

The second teacher insufficiently harmonised verbal and non-verbal communication three times in total, twice during offering materials and activities and once during the morning circle. Such harmonisation was sufficiently present 26 times, while the behaviour could not be observed once. In the reflection it could be noticed that the teacher was satisfied with the results of this social behaviour representation, giving a comment on how she had never thought about her nonverbal communication with children, and especially about its harmonisation with verbal contents. She also emphasized the need to raise awareness about the nonverbal form of communication with all kindergarten teachers because "we don't see ourselves and we forget about this type of communication." As far as the third kindergarten teacher is concerned, she insufficiently harmonised non-verbal communication with verbal three times, twice during breakfast and once during offering materials and activities, while it was adequately harmonised even 26 times. The behaviour was not suitable for observation once. This teacher was very satisfied with the result of this social behaviour since in the last few years she had been working on that a lot. She tried to correct her reactions in surprising situations and she was aware of the importance of this way of communication. She thought that it was difficult to control non-verbal communication because many times the facial expression revealed what speech tried to deny and conceal. There are gestures linked to emotions which people are not aware of in a certain moment if they are not warned about them.

\subsection{The kindergarten teacher carefully listens to children and follows them verbally/non-verbally}

Insufficiently careful listening to the child and following their expressions with some signs (yes, aha, ...) was present three times in the first teacher's behaviour, mostly during breakfast, while the stated behaviour was sufficiently present 
25 times, and once it could not be observed. The kindergarten teacher is of the opinion that the most important thing is to give the child feedback/reaction to what it, but also the adult, said or did and listen carefully, because its lack could cause bad self-conceptualisation of the child and the formation of a negative selfimage. Forming a positive self-image should be initiated in the early childhood, in their families, and continued in the kindergarten. This should be the aim of the community where the children grow up because they are dependent on their environment. Children should acquire positive thoughts about themselves for selfconceptualisation and confidence, and if they form a negative self-image, the influence of the kindergarten teacher/parent can lead to enormous changes (Brdar, Rijavec, 1998). Regarding the second kindergarten teacher, listening to children and following their speech with verbal/non-verbal signs is insufficiently present five times, mostly during offering materials and activities, less during other observed activities, while it was sufficiently present 23 times, with two situations when the behaviour could not be observed. Reflection indicates that the kindergarten teacher is satisfied with the results. She remarks that due to the large number of children in the educational group it is difficult to always hear and see each child who needs her. The situations when the behaviour was not sufficiently present regard moments when the teacher appeared not interested in what the child was saying, and moments when she was doing something else and did not follow the child's speech, nor did she confirm it, which according to the aforementioned means that she did not appropriately estimate her priority since the children had the impression that what they were saying was not important. One can give support and encourage the interlocutor with eye contact, smiling, raising eyebrows, nodding, using words such as oh, ah, aha, hm, yes,... Supporting and encouraging the interlocutor are unavoidable components of the communicational skill or active listening which should be known to kindergarten teachers since in that way they accept children's attitudes and experience and encourage their social and emotional development (Žižak et al., 2012).

The third teacher showed insufficient presence of careful listening to and verbally/non-verbally following the child totally six times, mostly during offering materials and activities and during breakfast, while the aforementioned was sufficiently present 23 times. Only once was this behaviour unsuitable for observation. The teacher expected such results. Since she was observed 30 times, the six times of insufficiently present behaviour show again that most of the time children were carefully listened to and followed during their speech. The insufficient presence of careful listening and following is argued by the organisation of time which determines the daily life rhythm in the educational group which (although flexibly 
adapted according to the children's needs and interest) she still sees as a limitation to the complete dedication to each child in the amount he/she would want.

\subsection{The kindergarten teacher carefully waits for the children to finish what they wanted to say}

The first kindergarten teacher did not carefully wait for the children to finish what they wanted to say six times, mostly during breakfast and the morning circle, while she did that 22 times, with two occasions when the behaviour could not be observed. The effectiveness of communication depends on the receptor's understanding of the message and on the achievement of the sender's aim (Žižak et al., 2012). Therefore, children's communication is not effective if their speech gets interrupted. Insufficient waiting time for the children to finish what they want to say relates to situations when the teacher was giving instructions to other children about performing and completing certain activities and when she was admonishing boys who were disturbing other children in their playing. According to reflection, the teacher is not fully satisfied with the results of this behaviour presence.

The second kindergarten teacher was insufficiently carefully waiting for the children to finish what they had to say four times, mostly during offering materials and activities, less during other observed activities. Careful waiting was sufficiently present 24 times, and twice it was not suitable for observation. According to the interview conducted with the teacher, she was satisfied that in most cases she waited carefully for children to finish what they wanted to say and did not interrupt them if there was no need for that. The situations when the children could not finish what they were saying because interrupted relate to moments when the teacher's urgent pedagogic interventions were necessary to help and constructively solve conflicts among children. As for the third teacher, insufficient waiting for the children to finish what they wanted to say appeared eight times, especially during offering materials and activities, and during breakfast, while sufficient waiting time appeared in 21 cases. One circumstance was not appropriate for observation. The teacher was not satisfied with the results, and during reflection she pointed out that it was important to direct children to express themselves and encourage them to think and come to conclusions. Each of them sees and experiences their environment in their own way, and by each answer and expression one can see the level of a child's learning and development which contributes to knowing the children and their way of thinking. The teacher feels sorry that obviously something seemed more important in the observed moment than waiting for the child to finish, arguing that probably there were potentially dangerous or unsafe situations, and that 
her intervention was certainly linked to the children's wellbeing. The destructiveness of interrupting a child is something Miljković et al. (2014) warn about due to the impediment of a deeper information processing and a negative influence to the development of the language, logics and control over events.

\subsection{The kindergarten teacher discreetly warns the children if they often shout or abuse their voice}

The first kindergarten teacher was insufficiently discrete in warning the children when they abused their voice (shouted) seven times in total, especially during breakfast and the morning cycle, while discrete warning was sufficiently present 23 times. Situations when she was insufficiently discrete in warning the children about their shouting relate to situations when she did not warn the child in any way, but ignored him/her. During the conversation with her it was revealed that this boy often reacted to her instructions and requests with resistance, disapproval and defiance resulting in his screaming and yelling. She most commonly ignores his shouting and does not warn him because she thinks this is not a developmental but educational problem ("the child is spoiled and often pampered, so he wants to get attention in such a way"), and she knows how to set discipline since she spends a lot of time with him and knows his character. Child learning, i.e. acquisition of knowledge based on set boundaries imposed to children by adults to make them follow rules can be called discipline, and the choice of adequate disciplinary techniques depends on the type of unacceptable behaviour, children's age, their character and educational style. Negative consequences such as "time-out" or verbal reprimand should be moderately used, but without yelling (Runkel 2008).

If a child often shouted or abused his/her voice in any other way, the second teacher did not warn him/her nine times, most noticeably during the morning circle and offering materials and activities, while a discrete intervention was sufficiently present 20 times. The behaviour was not appropriate for observation once. This teacher did not warn the shouting child discretely nine times, but she gathered all the children and denounced and admonished the "guilty one" in front of all other children. She did not see that as labelling a child or "putting them on a pillory", but wanted children to learn from other's mistakes and remind them all about the educational group rules. She tried for all the children to get a message about what is correct and what is not, and to make them take over responsibility for their own behaviour. In the observed educational work, the third kindergarten teacher did warn children discretely enough in 11 cases, especially during offering materials and activities and during breakfast, while discrete warning about the child's 
shouting or discrete abuse of voice was sufficiently present in 19 cases. One of the kindergarten's roles is the preventive role, because by the promotion of prosocial behaviour the kindergarten achieves this, along with the parallel development of the ability of cooperation and non-violent problem solving by aligned educational procedures in the relation family-educational institution, training children to respect others and their needs and wishes and by creating a pleasant and supporting atmosphere (Jurčević Lozančić, 2005).

\subsection{The kindergarten teacher conducts speech-supportive activities}

The conduction of speech development supportive activities was not applicable in the first kindergarten teacher's work 11 times, once during a collective attendance of a show and 10 times during breakfast. Namely, every day during breakfast the teacher waits for the children to gather and after the morning gathering they go to the breakfast table together. This represents their common time at the table where they cherish adequate cultural habits, develop the feeling of community and acquire the norms of polite behaviour during a meal. They remain sitting at the table regardless of the fact that someone has finished their meal, they wait for the rest to finish eating, and then they start cleaning the cutlery and putting it in the place meant for that. During breakfast the teacher did not conduct speech-supportive activities (stories, picture books, drama and scene activities, songs, rhymes) to stick to the formerly agreed rules of the group and not to disrupt the daily rhythm of the educational group. Furthermore, the conduction of activities which support the children's development of speech was insufficiently present once during offering materials and activities, and it was sufficiently present 18 times.

The second kindergarten teacher applied speech development activities to a sufficient extent 15 times. It showed to be insufficiently present 13 times, exclusively during breakfast ad offering materials and activities, and in two cases the behaviour was not appropriate for observation. The second teacher, contrary to the first one, does not insist on common breakfasts, and therefore, as usual, children who completed their meal rose from the table and took games they were interested in themselves choosing among the offered incitements. Regarding the fact that the teacher encouraged children in this time point, too, it was observed if those were speech-supportive, while in the case of insufficient conduction of such activities, it was estimated as insufficiently present behaviour, not one that could not be observed. During reflection the teacher gave a comment that she was not satisfied with the results about the occurrence of such activities in her work because she 
was aware of the importance of such activities. She remarked that what she offered more were activities to discover visual arts techniques and the expression of such experience, as well as the manipulation of different means, simple problem solving activities and activities for the development of physical and psychomotor development. She pointed out that during activities she verbalized everything going on and encouraged communication among children, but she also noticed that it was necessary to design and form a supporting drama centre as a constituent activity centre of activities in the daily room for children to listen to stories and rhymes and play with their emotions, use puppets to act, retell the content of stories and perform their own scene improvisations.

The third kindergarten teacher insufficiently conducted activities promoting speech, language and storytelling development six times, exclusively during offering materials and activities, while such activities were sufficiently present 13 times. Of the total number of behaviour observations, the behaviour was estimated as unsuitable for observation 11 times. Such a number of unsuitable behaviour is linked to the same reason as with the first kindergarten teacher. The teacher was of the opinion that such activities were necessary in the educational work, but she remarked that she personally followed children's interests and did not conduct her planned activities if children did not show an interest for them. She pointed out that speech could not remain undeveloped because it was impossible not to communicate, and that through various types of activities (research-cognitive, specific activities with movements, life-practical and working activities, social-entertaining activities, etc.) the speech and linguistic development was supported because children communicate through games and research through various different interactions going on naturally during the day.

\subsection{The kindergarten teacher gives clear and unambiguous instructions to children for the fulfilment of activities}

Regarding the first kindergarten teacher, clear instructions for the fulfilment of activities were insufficiently present in four cases, more times during breakfast, less in other observed activities, while adequate instructions were present 26 times. During reflection the teacher pointed out the importance of the way of how instructions were given, it was very important to children that the content of the message be clear and understandable, and what was also important to her was the approach to the child and the way instructions were given: if necessary, explanations should be given, especially when it is important that the child do something, for instance, hand-washing after using the toilette. The instruction should be of a 
strong character. If the child is asked to wash his/her hands, it should sound nicely, but what is missing is a dose of clear instruction to do that immediately and not to argue about that. During observation, the second teacher gave insufficiently clear instructions only three times, during offering materials and activities, while in the remaining 27 cases the presence of instructions which were clear, meaningful and concise to children was observed as sufficient. This teacher takes care about the way she expresses herself and communicates with children, she uses a language and vocabulary adequate for the children's age and gives clear and meaningful instructions for the fulfilment of activities. She remarked that it must not be neglected that wrong instructions may be the reason for a child's disobedience.

The third kindergarten teacher gave insufficiently clear instructions to children for the fulfilment of activities in three cases, also during offering materials and activities, while clear instructions in this teacher's work were sufficiently present 27 times. According to the reflection results, the teacher thinks that she is already experienced in giving instructions for the fulfilment of certain activities because in only one day the amount of instructions given to children was enormous, and she adds that an appropriate tone, amount and adequate choice of words are significant.

Results show that kindergarten teachers use theoretically adequate forms of social behaviour in working with children in more than $60 \%$ of cases. The following behaviours prevail as sufficiently present: warm and pleasant communication with children, clear and unambiguous instructions for the fulfilment of activities, harmonisation of non-verbal and verbal communication, careful listening to the child and following his/her speech and establishment of eye contact during communication. The less present behaviours in the three kindergarten teachers are as follows (from the most observed insufficiently present behaviour): conduction of speech-supportive activities, asking open-ended questions, discrete warning of children, careful waiting for the children to finish what they wanted to say, clear and articulate speech. Besides, all three teachers are familiar with the theoretically appropriate forms of behaviours in working with children, children's needs and interests, their developmental physiology, educational styles which they can use for interventions, and they know how to corroborate the wanted behaviour. Most importantly, they recognise the value of conducting such a research, show critical thinking toward their own work and readiness for further evaluation, they notice flaws which they want to work on and show a rational wish for the advancement and perfection of the quality of their work. 


\section{CONCLUSIONS}

This paper's aim was to study the chosen communication-social segment of the social learning in the educational work, with the purpose of the partial evaluation of kindergarten teachers' behaviours working with three different educational groups. The first research aim was to determine if the kindergarten teachers use adequate and theoretically appropriate forms of professional social behaviours, while the second was to gain an insight into the attitudes and reflection of the participating teachers about the results of the observed presence of certain forms of behaviour in their work. According to basic results, the three kindergarten teachers in a kindergarten in Zagreb mostly use professionally adequate and theoretically justified forms of behaviour in leading the educational group. Moreover, they are ready to objectively contemplate about areas of their work improvement, mostly reflected in the area of fine communication skills which need to be practiced, awoken and nourished through their professional career (speech-stimulating activities, asking open-ended questions, discretely warning children, careful waiting for the child to finish what he/she wanted to say, clear and articulate speech). Comparing these results with similar research results in Croatia (Kožić et al., 2013; Družinec, Velan, 2017), it can be said that educational workers are interested in and motivated for successful and adequate communication, but they also give utmost importance to adequate and stimulating social interaction.

In future research studies it would be advisable to choose other points in time and observations of the influence which other forms of social behaviours have, and do that on a larger sample of kindergarten teachers from various kindergartens as to obtain more reliable results. It would also be good to have a larger number of observers. Secondly, there is a need for more detailed research which would present the whole context, space and materials which are at the children's disposal, inspirational physical environment which in a special way forms social interactions between kindergarten teachers and children. Besides the ones mentioned in this paper, there are probably more possible reasons why the kindergarten teachers apply or not the theoretical postulates and principles in their work for which it is known can have a constructive and stimulating influence on the child. These reasons can tackle the culture of the educational institution (Vrcelj, 2003; Vujičić, 2011) which by its organisational predestination and interpersonal relationships may significantly support teachers' quality work. In spite of the methodological limitation that sometimes a rare occurrence of a certain form of behaviour is sufficient, and sometimes, if the behaviour is more usual, it does not have an effect, it is necessary to look for answers linked to the frequency and effectiveness of pro- 
fessionally desirable social behaviours in a scientific way. The conducted research confirms the role of the kindergarten teacher in forming desirable children's social behaviours, but practice shows differences among kindergarten teachers, so it is necessary to describe and analyse it, in other words, regularly "reflect" upon it. Katz and McClellan (1999) point out that the competence developed in relationships with others includes mixing feelings, thoughts and skills, and therefore this development needs a lot of time. Its basis is formed from the early childhood by parents, kindergarten teachers and other adults from the child's environment who are patient, considerate and kind.

The observed changes which form interactions, but also the atmosphere in the group can be counted as part of the hidden curriculum, mostly due to the reason that the concept of the hidden curriculum also includes "unnoticed standardisation and norming of interpersonal relationships which establish the pattern situation for the acquisition of socially desirable interpersonal orientations" (Bašić, $2000,171)$ and learning how to establish quality personal relationships as early as in childhood. It is emphasized that the hidden curriculum is used in a positive way when life in the kindergarten and school imitates real life as authentically as possible. Children then have the possibility to learn the skills of constructive decision making, which are more than necessary in their everyday life (Vlah et al., 2015; Jančec et al., 2015). Jančec and Lepičnik Vodopivec (2017) point out the crucial importance raising consciousness about the existence of the hidden curriculum in education because it symbolises the orientation point for future behaviours, reasoning and choices made by children and young persons while being prepared for life which does not start at a certain age, but in the moment of birth, of becoming part of a family or an educational institution - especially the community of professionals, reflexive practitioners whose mission is to enable children to gain learning experience. The part belonging to the quality of this experience, i.e. to the way learning conditions are formed, is unneglectable. A socially competent child uses his/her social possibilities and support from the environment in achieving the inclusion and functioning inside the group, and it is possible that the social experience gained in the first five or six years of life gives grounds for all future relationships (Katz, McClellan, 1999). Loughran (2002) especially emphasizes that for an effective reflexive practice, which is estimated as key in the direct work for professional growth and development, it is crucial to work with real examples from experienced practice and key to become a better practitioner. The authors hope that the presented research is a contribution to this.

The research determined that there is a need for tools, trainings and educations for the improvement of (self)evaluation of their own communication or 
other important skills to be offered to kindergarten teachers, for them to be able to form and change personal social skills and competencies. This also relates to the wide range of educations for which kindergarten teachers, through regular and common reflections, show an interest in as to become (socially) more competent professionals. Such educations can be conducted as part of modernised study programmes, but also through lifelong learning, in formal and informal ways, organised by sole kindergartens or professional agencies dealing with that.

„This work has been supported by the University of Rijeka under the project number uniri-drustv-18-98 1233“ 


\section{REFERENCES}

1. Bandura, A. (1986). Social Foundation of Thought and Action: A social cognitive theory. Englewood Cliffs, NJ: Prentice-Hall.

2. Boyes, C. (2009). Jezik tijela: tajni jezik gesti i držanja. Zagreb: Kigen.

3. Brajša, P., Vučetić, M. (1990). Osnovni elementi interpersonalne komunikologije. Varaždin: Fakultet organizacije i informatike.

4. Brdar, I., Rijavec, M. (1998). Što učiniti kad dijete dobije lošu ocjenu? Zagreb: IEP.

5. Bruner, J. (1981) The social context of language acquisition. Language and Communication, 1 (2-3): 155-178.

6. Dolar Bahovec, E., Bregar Golobič, K. (2004). Šola in vrtec skrozi ogledalo. Priročnik za vrtce. šole in starše. Ljubljana: DZS.

7. Družinec, V., Velan, D. (2017). Strategije odgojateljice u facilitiranju socijalnih interkacija djece u vrtiću. Studia Polinesia, 6 (1): 4-27.

8. Fleer, M., Hedegaard, M. Fleer (2010). Children's Development as Participation in Everyday Practices across Different Institutions. Mind, Culture, and Activity, 17(2): 149-168.

9. Hargreaves, A., Fullan, M. (1992). Understanding Teacher Development. London, Cassell / New York: Teachers College Press.

10. Jančec, L., Tatalović Vorkapić, S., Lepičnik Vodopivec, J. (2015). Hidden curriculum determinants in (pre)school institutions - implicit cognition in action. U Jin. Z. (ur.) Implicit Cognition: Learning. Memory. and Social Cognitive Processes. (pp. 216-242). USA: IGI Global.

11. Jančec, L., Lepičnik-Vodopivec J. (2017). Hidden curriculum determinates in kindergartens and in schools. Hamburg: Verlag Dr. Kovač.

12. Jurčević-Lozančić, A. (2005). Izazovi odrastanja. Petrinja: Visoka učiteljska škola.

13. Jurčević Lozančić A. (2011). Teorijski pogledi na razvoj socijalne kompetencije predškolskog djeteta. Pedagogijska istraživanja, 8 (2): 271-279.

14. Jurčević Lozančić, A. (2016). Socijalne kompetencije u ranom djetinjstvu. Zagreb: Učiteljski fakultet Sveučilišta u Zagrebu.

15. Katarinčić, I., Velički, V. (2011) Stihovi u pokretu- Malešnice i igre prstima kao poticaj za govor. Zagreb: Alfa.

16. Katz, L. G., Mcclellan, D. E. (1999). Poticanje razvoja dječje socijalne kompetencije. Zagreb: Educa.

17. Kožić, D., Globočnik-Žunac, A., Bakić-Tomić, Lj. (2013). Use of Non-verbal Communication Channels in the Classroom. Croatian Journal of Education 15 (1): 141-152.

18. Lesourne, J (2000). Obrazovanje i društvo: izazovi 2000. godine. Zagreb: Educa.

19. Loughran, J. J. (2002). Effective reflective practice in search of meaning in learning about teaching. Journal of teacher education, 53(1): 33-43.

20. Ljubetić, M. (2009). Vrtićpo mjeri djeteta. Zagreb: Školske novine.

21. Miljković, D., Rijavec, M., Vizek Vidović, V., Vlahović-Štetić, V. (2014) Psihologija obrazovanja. Zagreb: IEP-VERN 
22. Mlinarević, V. (2000). Kompetencija odgojitelja i autonomija djeteta. U: Babić, N. i Krstović, J. (ur.) Interakcija odrasli - dijete i autonomija djeteta: zbornik radova sa znanstvenog kolokvija s međunarodnim sudjelovanjem (pp.143-150). Osijek: Visoka učiteljska škola.

23. Mlinarević, V., Tomas, S. (2010). Partnerstvo roditelja i odgojitelja-čimbenik razvoja socijalne kompetencije djeteta. Magistra Iadertina, 5 (5), 143-158.

24. Nacionalni kurikulum za rani i predškolski odgoj i obrazovanje (2014.). Zagreb: MZOS.

25. Petrović-Sočo, B. (2000). Redefiniranje uloge odgojitelja u konstruktivističkom pristupu dječjem učenju. U: Slunjski, E (ur.) Učiti zajedno s djecom - učiti. (pp 19-22). Dječji centar Čakovec: Visoka učiteljska škola Čakovec.

26. Petrović Sočo, B. (2009). Mijenjanje konteksta i odgojne prakse dječjih vrtića. Zagreb: Mali profesor.

27. Rade, R. (2003) Poticanje ranog govorno-jezičnog razvoja. Zagreb: FOMA.

28. Runkel, H. E. (2008.) Odgojite svoje dijete bez vikanja : revolucionarni pristup smirenom odgoju djece. Zagreb: V.B.Z.

29. Slunjski, E., Šagud, M., Brajša-Žganec, A. (2006). Kompetencije odgojitelja u vrtiću - organizaciji koja uči. Pedagogijska istraživanja, 3 (1): 45-58.

30. Slunjski, E. (2008). Dječji vrtić: zajednica koja uči. Zagreb: Školska knjiga.

31. Slunjski, E. (2011). Kurikulum ranog odgoja: istraživanje i konstrukcija. Zagreb: Školska knjiga.

32. Tatalović Vorkapić, S., Srok, R. (2014). Treba li odgojiteljima smisao za humor. Dijete, vrtić, obitelj, 75: 9-11.

33. Turnšek, N. (2008). Subjektine teorije o otroštvu in vzgoji. Ljubljana: Pedagoška fakulteta Univerze v Ljubljani.

34. Velički, V. (2009). Poticanje govora u kontekstu zadovoljenja dječjih potreba u suvremenom dječjem vrtiću. Metodika: časopis za teoriju i praksu metodika u predškolskom odgoju, školskoj i visokoškolskoj izobrazbi, 10 (18): 80-91.

35. Vlah, N., Štifter, S., Bijedić, M. (2014). Some Aspects of the Phenomenology of Risk Behavior at Preschool Age, Defektologija, 20 (2): 130-136.

36. Vlah, N., Jančec, L., Čepić, R. (2015). Teachers' Attitudes towards Behaviour Patterns in Social Conflicts in Primorsko-Goranska County in Croatia. Center for Educational Policy Studies Journal, 5 (4): 125-141.

37. Vlah, N., Ferić, M. (2017). The need for additional support for nursery school children and the reasons why it is not provided: a teachers' perspective. Napredak, 158 (4): 461-481.

38. Vrcelj, S. (2003), Školska kultura - faktor kvalitete. U: Kramar, M. i Duh, M. (ur.): Didaktični in metodični vidiki prenove in razvoja izobraževanja: knjiga referatov $z$ 2. mednarodnega znanstvenega posveta. (pp. 87-95). Maribor: Pedagoški fakultet.

39. Vujičić, L. (2011). Istraživanje kulture odgojno-obrazovne ustanove. Rijeka: Sveučilište u Rijeci.

40. Zillmann, D., Bryant, J.(1980). Misattribution theory of tendentious humor, Journal of Experimental Social Psychology, 16 (2): 140-160.

41. Zrilić, S. (2010). Kvaliteta komunikacije i socijalni odnosi u razredu. Pedagogijska istraživanja, 7 (2): $231-242$.

42. Žižak, A., Vizek Vidović, V., Ajduković, M. (2012). Interpersonalna komunikacija u profesionalnom kontekstu. Zagreb: Edukacijsko-rehabilitacijski fakultet. 


\section{ODGOJITELJI KAO MODELI I FACILITATORI} SOGIJALIZAGIJE U VRTIĆU

\section{SAŽETAK}

U okviru teorije socijalnog učenja, ciljevi su bili (i) sudioničkim opažanjem utvrditi koriste li odgojiteljice adekvatne i teorijski primjerene oblike profesionalnih socijalnih ponašanja i (ii) analizirati njihov refleksivni osvrt na utvrđene rezultate profesionalnih socijalnih ponašanja. Uz pomoć obrasca Protokola sudioničkog praćenja opažano je deset socijalnih ponašanja, a nakon prikupljenih podataka, sa svakom je sudionicom proveden polustrukturirani upitnik za refleksivni osvrt. Rezultati pokazuju da je u ponašanju odgojiteljica pretežno prisutna topla i ugodna komunikacija s djecom, jasne i nedvosmislene upute za izvršavanje aktivnosti, usklađivanje verbalne i neverbalne komunikacije, pažljivo slušanje djeteta i uspostavljanje kontakta očima. Rjeđe se pojavljuju govorno-stimulativne aktivnosti, postavljanje otvorenih pitanja, diskretno upozoravanje djece te čekanje da dovrši što je željelo reći i razgovijetan govor. U refleksijama sve tri odgojiteljice pokazuju samokritičnost i racionalnu želju za unapređenjem kvalitete rada.

Ključne riječi: odgojitelj, teorija socijalnog učenja, socijalizacija, refleksivna praksa, skriveni kurikulum 


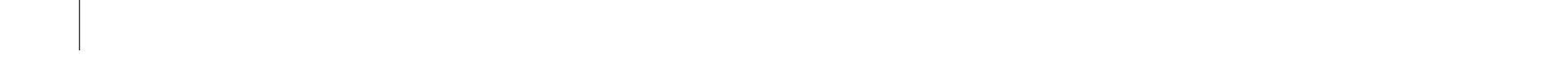

